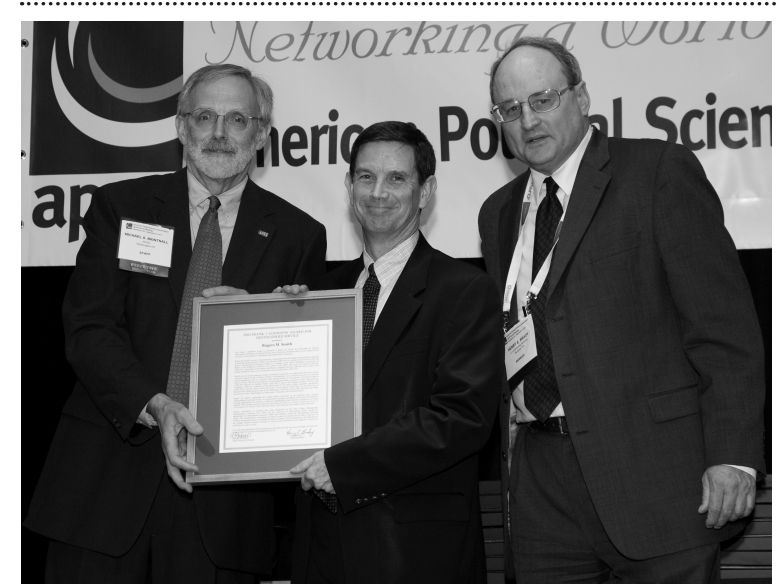

APSA executive director Michael Brintnall (left) and APSA president Henry Brady (right) pose with Rogers M. Smith after he received the Goodnow Award at the Awards Ceremony

and as chair of the Annual Meeting Division on Constitutional Law and Jurisprudence (2001-02).

His service to the profession reaches beyond the Association, as evidenced by his service on the Advisory Council for the Teachers Institute of Philadelphia; as an external reviewer to 12 political science departments; and as a member of the edi- torial boards of nine journals. During his tenure at Yale University, he served as the director of undergraduate studies in political science and economics (1986-88); director of graduate studies (1999-2001); chair of the Program of Ethics, Politics, and Economics (1989-91); codirector of the ISPS Center for the Study of Race, Inequality, and Politics (1995-2001); and the Alfred Cowles Professor of Government (1999-2001). At the University of Pennsylvania, he has been chair of the department of political science (2003-06) and, since 2006, has served as chair of the Program on Democracy, Citizenship, and Constitutionalism.

His scholarship has created greater discussion of the discipline and a greater understanding of political science. As an advocate for dialogue and debate, he has been instrumental in creating opportunities for scholars of different methodological and theoretical perspectives to come together. The numerous awards received for his book Civic Ideals: Conflicting Visions of Citizenship in U.S. History (Yale UP, 1999) are proof of his impact on the profession.

His contributions to teaching have been recognized by the Yale College Distinguished Undergraduate Teaching Prize (1984) and the University of Pennsylvania Dean's Award for Mentorship of Undergraduate Research (2008) and Lindback Award for Distinguished Teaching (2009). His commitment to encouraging excellence in others is evidenced by his role as supervisor of $33 \mathrm{Ph}$.D. dissertations and as a committee member on another 52 Ph.D. dissertations. His dedication to the younger political scientists through his work on such committees will continue to impact the profession for years to come.

It is with deep appreciation for these scholars' dedication to the profession that the APSA presented to them the Frank J. Goodnow Award for Distinguished Service. -

\title{
APSA's Organized Sections Distributed Awards at the 2010 Annual Meeting in Washington, DC
}

\begin{abstract}
T $\mathrm{n}$ addition to the awards presented at the APSA Awards Ceremony on Thursday, September 2, the following recognitions were announced at the business meetings and receptions of the APSA Organized Sections.
\end{abstract}

\section{SECTION 1: FEDERALISM AND INTERGOVERNMENTAL RELATIONS Daniel Elazar Distinguished Federal- ism Scholar Award}

The Daniel Elazar Distinguished Scholar Award recognizes a lifetime of contributions to the study of federalism and intergovernmental relations.

Award Committee: Jeremy Hall, University of Texas, Dallas, chair; Cheryl Collier, University of Windsor; John Dinan, Wake Forest University

Recipient: Richard Simeon, University of Toronto

\section{Deil Wright Best Paper Award}

The Deil Wright Best Paper Award is pre- sented to the author of the best paper on federalism and intergovernmental relations presented at the last APSA Annual Meeting.

Award Committee: Carolyn Johns, Ryerson University, chair; Shama Gamkhar, University of Texas at Austin; Christopher Borick, Muhlenberg College

Recipient: Jennifer Wallner, University of Regina, Canada

Title: "Does Diversity Always Lead to Decentralization and Difference?"

\section{Martha Derthick Best Book Award}

The Martha Derthick Best Book Award is presented to the author of a book published at least 10 years ago that has made a lasting contribution to the study of federalism and intergovernmental relations.

Award Committee: Kiki Caruson, University of South Florida, chair; Patrick McGuinn, Drew University; Edella Schlager, University of Arizona

Recipient: Paul E. Peterson, Harvard Uni- versity

Title: The Price of Federalism (Brookings Institution Press, 1995)

\section{SECTION 3: LEGISLATIVE STUDIES Alan Rosenthal Prize}

In the spirit of Alan Rosenthal's work, this prize is dedicated to encouraging young scholars to study questions that are of importance to legislators and legislative staff and to conduct research that has the potential application to strengthening the practice of representative democracy. Award Committee: Michele Swers, Georgetown University, chair; Christopher Berry, University of Chicago; John Griffin, Notre Dame University

Recipients: David C.W. Parker, Montana State University, and Craig Goodman, Texas Tech University

Title: "Making a Good Impression: Resource Allocation, Home Styles and Washington Work," Legislative Studies Quarterly 34 (4): 493-524 


\section{CQ PRESS AWARD}

The CQ Press Award is given for the best paper on legislative studies presented at the previous year's APSA Annual Meeting. Award Committee: Lauren Bell, Randolph Macon College, chair; Kenneth Shotts, Stanford University; Garry Young, George Washington University

Recipient: Christian Grose, Vanderbilt University

Title: "Priming Rationality: A Theory and Field Experiment of Participation in Legislatures"

\section{Jewell-Loewenberg Award}

The Jewell-Loewenberg Paper Award is presented for the best article in the Legislative Studies Quarterly in the previous year. Award Committee: Cherie Maestas, Florida State University, chair; Neil Malhotra, Stanford University; Jamie Carson, University of Georgia

Recipient: Sebastian M. Saiegh, University of California, San Diego

Title: "Recovering a Basic Space from Elite Surveys: Evidence from Latin America," Legislative Studies Quarterly 34 (1): 117-43

\section{Richard F. Fenno Prize}

In the tradition of Professor Fenno's work, this prize is designed to honor work that is both theoretically and empirically strong. Moreover, this prize is dedicated to encouraging scholars to pursue new and different avenues of research in order to find answers to previously unexplored questions about the nature of politics.

Award Committee: Damon Cann, Utah State University, chair; Linda Fowler, Dartmouth College; C. Lawrence Evans, College of William and Mary

Recipient: Frances Lee, University of Maryland, College Park

Title: Beyond Ideology: Politics, Principles, and Partisanship in the U.S. Senate (University of Chicago Press, 2009)

\section{Carl Albert Dissertation Award}

The Carl Albert Dissertation Award is given for the best doctoral dissertation in the area of legislative studies.

Award Committee: Robin A. Kolodny, Temple University, chair; Tom Clark, Emory University; Andrew Taylor, North Carolina University

Recipient: Patrick Egan, New York University

Title: "Issue Ownership and Representation in American Politics" (Ph.D., Berkeley, 2008)
SECTION 4: PUBLIC POLICY

\section{Best Paper on Public Policy Award}

The Best Paper Award is given for the best paper on public policy given at the previous APSA Annual Meeting.

Award Committee: Jennifer Hochschild, Harvard University, chair; Ann Bowman, Texas A\&M University; Doug Imig, University of Memphis

Recipients: Eric Patashnik, University of Virginia, and Julian Zeiler, Princeton University

Title: "When Policy Does Not Remake Politics: The Limits of Policy Feedback"

SECTION 5: POLITICAL ORGANIZATIONS AND PARTIES

\section{Jack L. Walker, Jr. Award}

This award honors an article published in the last two calendar years that makes an outstanding contribution to research and scholarship on political organizations and parties.

Award Committee: Paul Goren, University of Minnesota, chair; Robert Van Houweling, University of California, Berkeley; Michael Tomz, Stanford University

Recipients: Cathie Jo Martin, Boston University, and Duane Swank, Marquette University

Title: "The Political Origins of Coordinated Capitalism: Business Organizations, Party Systems, and State Structure in the Age of Innocence," American Political Science Review 102 (2): 181-98

\section{Leon Epstein Outstanding Book Award}

This award honors a book published in the last two calendar years that makes an outstanding contribution to research and scholarship on political organizations and parties.

Award Committee: John Green, University of Akron, chair; Larry Bartels, Princeton University; John Coleman, University of Wisconsin-Madison

Recipients: Frank Baumgartner, University of North Carolina, Chapel Hill; David Kimball, University of Missouri, Saint Louis; Marie Hojnacki, Pennsylvania State University; Beth Leech, Rutgers University; and Jeffrey Berry, Tufts University

Title: Lobbying and Policy Change: Who Wins, Who Loses and Why (University of Chicago Press, 2009)

\section{Samuel J. Eldersveld Award}

This award honors a scholar whose lifetime professional work has made an outstand- ing contribution to the field.

Award Committee: L. Sandy Maisel, Colby College, chair; Jeffrey Berry, Tufts University; Ruth S. Jones, Arizona State University Recipient: David W. Rohde, Duke University

\section{Emerging Scholar Award}

This honor is awarded to a scholar who has received his or her Ph.D. within the last seven years and whose career to date demonstrates unusual promise.

Award Committee: Christina Woldbrecht, University of Notre Dame, chair; Peter Francia, East Carolina University; Hans Noel, Georgetown University

Recipient: David Karol, American University

\section{Perspectives on Politics/Party Politics Award}

This award honors the best paper presented on a Perspectives on Politics panel at the previous APSA Annual Meeting.

Award Committee: Marie Hojnacki, Pennsylvania State University, chair; John Aldrich, Duke University; David Dulio, Oakland University

Recipients: Seth Masket, University of Denver; Michael Heaney, University of Michigan; Joanne Miller, University of Minnesota; Dara Strolovitch, University of Minnesota, Twin Cities

Title: "Networking the Parties: A Comparison of Democratic and Republican National Convention Delegates in 2008"

SECTION 6: PUBLIC ADMINISTRATION

\section{Herbert Kaufman Award}

The Herbert Kaufman Award is given for the best paper presented at the previous APSA Annual Meeting.

Award Committee: Jerrell D. Coggburn, North Carolina State University, chair; Lael Keiser, University of Missouri, Columbia; Eric Zeemring, San Francisco State University

Recipients: Jeffrey L. Brudney, Cleveland State University; Chung-Lae Cho, Ewha Woman's University; Deil S. Wright

Title: "Sector Choice: Its Role in Explaining Contracting Performance"

Honorable Mention: Jennifer Bussell, University of Louisville

Title: "Evaluating Public Service Reforms in India"

\section{Herbert Simon Book Award}

The Herbert Simon Book Award is con- 
ferred annually for the best book on public administration published in the last three to five years that has made a significant contribution to public administration scholarship.

Award Committee: Michael A. Pagano, University of Illinois, Chicago, chair; Norma M. Riccucci, Rutgers University, Newark; Brian K. Collins, University of North Texas Recipient: Paul Light, New York University

Title: A Government Ill Executed: The Decline of the Federal Service and How to Reverse It (Harvard University Press, 2008)

\section{Volcker Junior Scholar Research Grant}

The Volcker Junior Scholar Research Grant is awarded to a junior scholar researching public administration issues affecting governance in the United States and abroad.

Award Committee: Charles W. Gossett, California State University, Sacramento, chair; Thomas P. Lauth, University of Georgia; Sally Selden, Lynchburg College

Recipient: Amanda Girth, American University

SECTION 9: PRESIDENCY RESEARCH The Founder's Award (Ph.D.)

The Founder's Award (Ph.D.), named in honor of Stephen Wayne, is given for the best paper presented by a graduate student at either the preceding year's APSA Annual Meeting or at any of the regional meetings in the past two calendar years.

Award Committee: B. Dan Wood, Texas A\&M University, chair; Brandice CanesWrone, Princeton University; Julia Azari, Marquette University; Daniel DiSalvo, City College of New York; Bruce Nesmith, Coe College

Recipient: Amnon Cavari, University of Wisconsin-Madison

Title: "The Presidential Rhetoric and the Economic Policy Image of the Parties"

\section{The Founder's Award}

The Founder's Award, named in honor of James Young, is given for the best paper presented by a Ph.D.-holding scholar at the previous year's APSA Annual Meeting. Award Committee: John Woolley, University of California, Santa Barbara, chair; George Edwards, Texas A\&M University; Dan Galvin, Northwestern University; Brian Newman, Pepperdine University; James King, University of Wyoming

Recipient: Kevin J. McMahon, Trinity College
Title: "Richard Nixon, the Supreme Court, and the Politics of Desegregation in the Urban North"

\section{Richard E. Neustadt Best Reference Book Award}

The Richard E. Neustadt Award is given for the best reference book published during the previous year.

Award Committee: Joel Aberbach, University of California, Los Angeles, chair; Anthony Bertelli, University of Southern California; George Krause, University of Pittsburgh

Co-Recipient: George C. Edwards, Texas A\&M University, and William Howell, University of Chicago

Title: The Oxford Handbook of the American Presidency (Oxford University Press, 2009) Co-Recipient: Lyn Ragsdale, Rice University

Title: Vital Statistics on the Presidency, Third Edition (CQ Press, 2009)

\section{Richard E. Neustadt Award for the Best Book on the Presidency}

The Richard E. Neustadt Award is given for the best book on the U.S. presidency published during the previous year.

Award Committee: Paul Quirk, University of British Columbia, chair; William Howell, University of Chicago; Matthew Beckmann, University of California, Irvine; Martha Joynt Kumar, Towson State University; Richard Waterman, University of Kentucky

Recipient: B. Dan Wood, Texas A\&M University

Title: The Myth of Presidential Representation (Cambridge University Press, 2009)

\section{Best Undergraduate Paper Award}

This award is given for the best undergraduate paper completed in the past two academic years.

Award Committee: Lydia Andrade, University of the Incarnate Word, chair; Shannon Bow, University of Texas; Karen Hoffman, Marquette University; Jose Villalobos, University of Texas at El Paso; Diane Heith, Saint Johns University

Recipient: No award given

\section{George C. Edwards III Dissertation Award}

This award is given for the best dissertation on the presidency completed and accepted during the past calendar year.

Award Committee: Karen Hult, Virginia Polytechnic Institute \& State University, chair; Richard Powell, University of Maine;
Bert Rockman, Purdue University; Randy Adkins, University of Nebraska-Omaha; Christopher Kelley, Miami University of Ohio

Recipient: No award given

\section{SECTION 10: POLITICAL METHOD-} OLOGY

\section{Career Achievement Award}

The Career Achievement Award recognizes an individual whose work in political methodology has demonstrated outstanding intellectual accomplishment and service to the profession.

Award Committee: Janet M. Box-Steffensmeier, Ohio State University, chair; Nancy Burns, University of Michigan; Jake Bowers, University of Illinois, Urbana-Champaign; John Jackson, University of Michigan; Tse-Min Lin, University of Texas, Austin

Recipient: Gary King, Harvard University

\section{Harold F. Gosnell Prize}

The Harold Gosnell Prize is given for the best work of political methodology presented at a political science conference between August 1, 2008, and July 31, 2009.

Award Committee: Kenneth W. Kollman, University of Michigan, chair; Betsy Sinclair, University of Chicago; Matthew Lebo, SUNY-Stony Brook

Recipient: Jong Hee Park, University of Chicago

Title: "Joint Modeling of Dynamic and Cross-Sectional Heterogeneity: Introducing Hidden Markov Panel Models"

\section{John T. Williams Award}

The award established for the best dissertation proposal in the area of political methodology in recognition of John T. Williams' contribution to graduate training.

Award Committee: Patrick T. Brandt, University of Texas at Dallas, chair; Michael Colaresi, Michigan State University; Betsy Sinclair, University of Chicago

Recipient: Teppei Yamamoto, Princeton University

\section{Society for Political Methodology Poster Award}

This award is given for the best poster presented at the 2009 Summer Conference on Political Methodology or the 2009 APSA Annual Meeting.

Award Committee: Suzanna Linn, Pennsylvania State University, chair; Curtis Signorio, University of Rochester; Karen Jusko, Stanford University; Dean Lacy, Dart- 
mouth University; William Clark, University of Michigan; Robert Erikson, Columbia University; Jana von Stein, University of Michigan; Drew Linzer, Emory University; Tom Carsey, University of North Carolina Recipients: R. Michael Alvarez, California Institute of Technology, and John Brehm, University of Chicago

\section{Statistical Software Award}

The Statistical Software Award recognizes statistical software that has made a significant contribution to the advancement of political analysis.

Award Committee: Jasjeet Sekhon, University of California, Berkeley, chair; Kosuke Imai, Princeton University; Micah Altman, Harvard University; Andrew Martin, Washington University, Saint Louis; Simon Jackman, Stanford University

Recipients: Jeffrey Dubin, University of California, Los Angeles; and Doug Rivers, Stanford University

\section{Warren Miller Prize}

The Warren Miller Price is given for the best article appearing in Political Analysis in the previous year.

Award Committee: J. Tobin Grant, Southern Illinois University, chair; David Darmofal, University of South Carolina; Michael Hanmer, University of Maryland, College Park

Recipient: Daniel Corstange, University of Maryland

Title: "Sensitive Questions, Truthful Answers? Modeling the List Experiment with LISTIT," Political Analysis 17 (1)

\section{SECTION 11: RELIGION AND POLI-}

\section{TICS}

Aaron Wildavsky Dissertation Award

The Aaron Wildavsky Award is given for the best dissertation on religion and politics successfully defended in 2008 or 2009. Award Committee: Ted Jelen, University of Nevada, Las Vegas, chair; Gamze Cavdar, Colorado State University; Mark Jendrysik, University of North Dakota; Ani Sarkissian, Michigan State University

Recipient: Karrie J. Koesel, University of Oregon

Title: "Belief in Authoritarianism, Religious Revivals, and the Local State in Russia and China"

\section{Paul J. Weber Award}

The Paul J. Weber Award is given for the best paper dealing with religion and politics presented at the 2009 APSA Annual
Meeting.

Award Committee: Elizabeth Oldmixon, University of North Texas, chair; Rodney Grunes, Centenary College; Sandy Livington, University of Aberdeen; Tarek Masoud, Harvard University

Recipient: No award given

\section{SECTION 13: URBAN POLITICS}

\section{Best Paper Award}

The Best Paper Award is presented to the best paper given at an Urban Politics Section panel at the previous year's APSA Annual Meeting.

Award Committee: Jered Carr, Wayne State University, chair; Yue Zhang, University of Illinois, Chicago; Benoy Jacob, University of Colorado, Denver

Recipient: Jen Nelles, University of Toronto

Title: "Cooperation and Capacity: Exploring the Sources and Limits of City-Region Governance Partnership"

\section{Best Dissertation in Urban Politics Award}

This award is given for the best dissertation on urban politics completed and accepted in the previous year.

Award Committee: E. Terrence Jones, University of Missouri-Saint Louis, chair; Hal Wolman, George Washington University; Kristin Good, Dalhousie University

Recipient: Joshua Sapotichne, University of Washington

Title: "Reconstructing National Urban Policy: Agenda Setting in Complex Policy Areas"

\section{Norton Long Career Achievement Award}

This award is presented annually to a scholar who has made distinguished contributions to the study of urban politics over the course of a career through scholarly publication, the mentoring of students, and public service.

Award Committee: Clarence Stone, George Washington University, chair; Wilbur Rich, Wellesley University; Ann O. M. Bowman, Texas A \& M University

Recipient: Susan Clarke, University of Colorado, Boulder

\section{Norton Long Young Scholars Award}

This award is given for scholars who completed their Ph.D. within the last three years (including ABDs) and submitted a paper proposal for the 2010 APSA Annual Meeting to the 2010 program chairs.
Award Committee: Mara Sidney, Rutgers University, Newark; Michael L. Owens, Emory University

Co-Recipient: Justin Gest, London School of Economics and Political Science

Title: "Alienation among European Muslims: Spanish Moroccans and British Bangladeshis"

Co-Recipient: Scott Louis Minkoff, University of Colorado, Boulder

Title: "A Space-Time Analysis of Local Competition and Cooperation"

Co-Recipient: Meg Elizabeth Rithmire, Harvard University

Title: "Closed Neighborhoods in Open Cities: The Politics of Socio-Spatial Change in Urban China"

Co-Recipient: Paolo Spada, Yale University Title: "The Effects of Participatory Democracy: Evidence from Brazilian Participatory Budgeting"

Co-Recipient: Manuel P. Tedodoro, Colgate University

Title: "Political Institutions and Environmental Policy Choices: Water Conservation in America"

\section{Best Book Award}

The Best Book Award is given for the best book on urban politics published in the previous calendar year.

Award Committee: Jessica Trounstine, University of California, Merced, chair; Jill Gross, CUNY-Hunter; Richard Fogelesong, Rollins College

Recipient: To be announced

\section{The Bryan Jackson Dissertation in Ethnic and Racial Politics Research Support Award}

This award is given to a graduate student studying racial and ethnic politics in an urban setting.

Award Committee: Yvette Alex-Assensoh, Indiana University, Bloomington; Peter Burns, Loyola University, New Orleans; Shah Shah, Macalester College

Recipient: Jamilia Celestine-Michener, University of Chicago

Title: "The Politics of Help Seeking in Marginalized Populations"

\section{SECTION 15: SCIENCE, TECHNOLOGY} \& ENVIRONMENTAL POLITICS

\section{Don K. Price Award}

The Don K. Price Award is given for the best book on science, technology, and environmental politics published in the past three years.

Award Committee: Dan Breznitz, Geor- 
gia Institute of Technology, chair; Steven Epstein, Northwestern University; Robert Paarlberg, Wellesley College

Recipient: Viktor Mayer-Schonberger, National University of Singapore

Title: Delete: The Virtue of Forgetting in the Digital Age (Princeton University Press, 2009)

\section{Lynton K. Caldwell Award}

The Lynton Keith Caldwell Prize is for the best book on environmental politics and policy published in the past three years.

Award Committee: Loren R. Cass, College of the Holy Cross, chair; Margaret E. Keck, Johns Hopkins University; Robert J. Duffy, Colorado State University

Recipient: Megan Mullin, Temple University

Title: Governing the Tap: Special District Governance and the New Local Politics of Water (MIT Press, 2009)

\section{Virginia M. Walsh Best Dissertation Award}

The Virginia M. Walsh Award is given for the best dissertation in science, technology, and environmental politics finished in the last two years.

Award Committee: Mark Zachary Taylor, Georgia Institute of Technology, chair; Phillip Stalley, DePaul University; Kathryn Hochstetler, University of Waterloo Recipient: Jennifer Bussell, University of Texas, Austin

Title: "Resisting Reform: Technological Backwardness in Political Perspective" Honorable Mention: Shelley L. Hurt, California Polytechnic State University, San Luis Obispo

Title: "Science, Power, and the State: United States Foreign Policy, Intellectual Property Law, and the Origins of Agricultural Biotechnology, 1969-1994" (New School for Social Research)

\section{SECTION 16: WOMEN AND POLITICS RESEARCH}

\section{Best Dissertation Award}

This award is given to the author of the best dissertation completed and successfully defended on women and politics written in the previous calendar year.

Award Committee: Lisa Garcia Bedolla, University of California, Berkeley, chair; Olga A. Avedyeva, Loyola University, Chicago; Maria C. Escobar-Lemmon, Texas A\&M University; Diana Michele Prindeville, New Mexico State University; Jennifer Nedelsky, University of Toronto
Recipient: Samantha Majic, John Jay College

Title: "Protest by Other Means? Sex Worker, Social Movement Evolution, and the Political Possibilities of Nonprofit Service Provision"

Dissertation Chair: Mary Fainsod Katzenstein, Cornell University

\section{Best Paper Award}

The Best Paper Award is given to the best paper presented at the previous year's APSA meeting on women and politics. Award Committee: Laura Woliver, University of South Carolina, chair; Penny Weiss, Saint Louis University; R. Amy Elman, Kalamazoo College; Sarah Childs, University of Bristol; Wendy Smooth, Ohio State University

Recipient: Celia Valiente, Universidad Carlos III, Madrid Spain

Title: "Political Regimes Matter in 'Abeyance' Times: Feminist Organizing in Franco's Spain (1930-1975)"

\section{The Okin-Young Award}

(Co-sponsored by Foundations of Political Theory and the Women's Caucus for Political Science)

The Okin-Young Award in Feminist Political Theory commemorates the scholarly, mentoring, and professional contributions of Susan Moller Okin and Iris Marion Young to the development of the field of feminist political theory. The award recognizes the best paper on feminist political theory published in an English language academic journal during the previous calendar year.

Award Committee: Kathy Ferguson, University of Hawaii, chair; Brooke Ackerly Vanderbilt University; Heike Schotten, University of Massachusetts, Boston

Recipient: Ann Towns, University of Delaware

Title: "The Status of Women as a Standard of 'Civilization,"' European Journal of International Relations 15 (4): 681-706

\section{SECTION 17: FOUNDATIONS OF}

\section{POLITICAL THEORY}

\section{The David Easton Award}

The David Easton Award is given for a book that broadens the horizons of contemporary political science by engaging issues of philosophical significance in political life through any of a variety of approaches in the social sciences and humanities.

Award Committee: Thomas Dumm,Amherst College, chair; Mark Blasius, CUNY Grad- uate Center; Melissa Orlie, University of Illinois-Urbana-Champaign

Recipient: George Shulman, New York University

Title: American Prophecy: Race and Redemption in American Political Culture (University of Minnesota Press, 2008)

Honorable Mention: Robert Gooding-Williams, University of Chicago

Title: In the Shadow of DuBois: Afro-Modern Political Thought in America (Harvard University Press, 2009)

Honorable Mention: Marc Epprecht, Queens University, Kingston Ontario Canada Title: Heterosexual Africa?The History of an Id a from the Age of Exploration to the Age of AIDS (Ohio University Press, 2008)

\section{Best Paper Award}

The Best Paper Award is given for the best paper presented on a foundation panel at the previous year's APSA Annual Meeting. Award Committee: Anna Marie Smith, Cornell University, chair; Patricia Moynagh, Wagner College; Linda M. G. Zerilli, University of Chicago

Recipients: Phillip Michelbach, West Virginia University, and Andrew Poe, University of California, San Diego

Title: "Renewing Democratic Authority: Hamlet's Politics with (and against) Carl Schmitt"

\section{First Book Award}

The First Book Award is given for a first book by a scholar in the "early stages of his or her career" in the area of political theory or political philosophy.

Award Committee: Patchen Markell, University of Chicago, chair; Brooke Ackerly, Vanderbilt University; Eloise A. Buker, Saint Louis University

Recipient: Jeffrey Edward Green, University of Pennsylvania

Title: The Eyes of the People: Democracy in an Age of Spectatorship (Oxford University Press, 2009)

Honorable Mention: Mark B. Brown, California State University, Sacramento

Title: Science in Democracy: Expertise, Institutions, and Representation (MIT Press, 2009)

Honorable Mention: Danielle Celermajer, University of Sydney

Title: The Sins of the Nation and the Ritual of Apologies (Cambridge University Press, 2009) 


\section{Best Graduate Student Paper Award}

The Best Graduate Student Paper Award recognizes the best sole-authored conference paper written by a political science graduate student working in the area of information technology and politics written during the previous calendar year.

Award Committee: David Karpf, University of Pennsylvania and Brown University; Christine Williams, Bentley College; Renee Marlin-Bennett, Johns Hopkins University

Recipients: Jessica Timpany Feezell, Meredith Conroy, and Mario Guerrero, University of California, Santa Barbara

Title: "Facebook is...Fostering Political Engagement: A Study of Online Social Networking Groups and Offline Participation"

\section{Best Book Award}

The Best Book Award is given for the best book on information technology and politics published in the previous calendar year.

Award Committee: Micah Altman, Harvard University, chair; Stuart Shulman, University of Massachusetts, Amherst; Priscilla Regan, George Mason University Recipients: Stephen Coleman, University of Leeds, and Jay G. Blumler, University of Leeds and University of Maryland Title: The Internet and Democratic Citizenship: Theory, Practice and Policy (Cambridge University Press, 2009)

\section{Best Instructional Political Science Website}

The Best Instructional Political Science Website Award recognizes the Website with the best instructional value for teaching political science.

Award Committee: Derrick Cogburn, American University, chair; Andrew Chadwick, University of London; Kenneth Rogerson, Duke University

Recipient: Chirag Shah, Rutgers University

Web Site: Context Miner, http://contextminer.com/index.php

Honorable Mention: Kenneth Janda and Jerry Goldman, Northwestern University; Jeffrey Berry, South Texas Community College

Web Site: IDEALog, http://idealog.org

SECTION 19: INTERNATIONAL SECURITY AND ARMS CONTROL

Kenneth N. Waltz Dissertation Prize

The Kenneth N. Waltz Dissertation Award is awarded to a successfully defended doctoral dissertation on any aspect of security studies that has been submitted in final, library copy in the 2009 year.

Award Committee: Andrew Dorman, Kings College London; Chris Demchak, Naval War College; David Sacko, U.S. Air Force Academy; Joshua Rovner, Naval War College

Recipient: Keren Yarhi Milo, University of Pennsylvania

Title: "Knowing Thy Adversary: Assessments of Intentions in International Relations"

\section{Joseph Kruzel Memorial Award for Public Service}

This award is given to a scholar who has been active in national security affairs both as an academic and a public servant.

Award Committee: Peter Feaver, Duke University, chair; Catherine Kelleher, Brown University; Steven Grenier, U.S. Army; Jeffrey Larsen, SAIC

Recipient: Stephen D. Krasner, Hoover Institution and Stanford University

\section{SECTION 20: COMPARATIVE POLI- TICS}

\section{Gregory Leubbert Best Article Award}

This award is given to the best article in the field of comparative politics published in the previous two calendar years.

Award Committee: Ruth Berins Collier, University of California, Berkeley, chair; Robert Pekkanen, University of Washington; Lily Tsai, Massachusetts Institute of Technology; Scott Gehlbach, University of Wisconsin-Madison

Recipients: Shawn Treier, University of Minnesota, and Simon Jackman, Stanford University

Title: "Democracy as a Latent Variable," American Journal of Political Science 52 (1)

\section{Gregory Luebbert Book Prize}

The Luebbert Book Award is given for the best book in the field of comparative politics published in the previous two years. Award Committee: Stephan Haggard, University of California, San Diego, chair; Ray Duch, University of Oxford; Randall Hansen, University of Toronto

Recipients: James Habyarimana, Georgetown University; Macartan Humphries, Columbia University; Daniel Posner, University of California, Los Angeles; Jeremy Weinstein, Stanford University

Title: Coethnicity: Diversity and the Dilemmas of Collective Action (Russell Sage)

\section{Lijphart/Przeworski/Verba Dataset} Award

The Dataset Award is given for a publicly available data set that has made an important contribution to the field of comparative politics.

Award Committee: Bo Rothstein, University of Gothenburg, chair; Jose Cheibub, University of Illinois, Urbana-Champaign; David Cingranelli, SUNY, Binghamton Recipient: Mark Tessler, University of Michigan, principal investigator; Amaney Jamal, Princeton University, co-principal investigator

Title: Arab Barometer

\section{Sage Best Paper Award}

The Sage Best Paper Award is given to the best paper in the field of comparative politics presented at the previous year's APSA Annual Meeting.

Award Committee: Dorothy J. Solinger, University of California, Irvine, chair; Matthew Adam Kocher, Yale University; Daniel ZIblatt, Harvard University

Recipient: Makus Kreuzer, Villanova University

Title: "Historical Knowledge and Quantitative Analysis: The Case of the Origins of Proportional Representation"

Honorable Mention: Grigore Pop-Eleches, Princeton University, and Graeme B. Robertson, University North Carolina, Chapel Hill

Title: "Elections, Information and Political Change in the Post-Cold War Era"

\section{SECTION 21: EUROPEAN POLITICS AND SOCIETY}

\section{Best Book Award}

The Best Book Award is given for the best book on European politics and society published in the previous year.

Award Committee: Bonnie Meguid, University of Rochester, chair; R. Daniel Kelemen, Rutgers University, New Brunswick; Gwendolyn Sasse, University of Oxford, Nufield College

Recipient: Grigore Pop-Eleches, Princeton University

Title: From Economic Crisis to Reform: IMF Programs in Latin America and Eastern Europe (Princeton University Press, 2009)

\section{Ernst B. Haas Best Dissertation Award}

The Ernst B. Haas Best Dissertation Award is given for the best dissertation on European politics and society filed during the previous year. 
Award Committee: Tanja A. Boerzel, Freie Universität Berlin, chair; Jane R. Gingrich, University of Minnesota, Twin Cities; Karl Orfeo Fioretos, Temple University

Recipient: Mareike Kleine, Freie Universität Berlin

Title: "All Roads Lead Away From Rome: A Liberal Theory of International Regimes"

\section{SECTION 22: STATE POLITICS AND} POLICY

\section{Best Paper Award}

The Best Paper Award is given for the best paper on state politics and policy presented at the previous year's APSA Annual Meeting.

Award Committee: James King, University of Wyoming, chair; Elizabeth Rigby, University of Houston; Neal Woods, University of South Carolina

Recipients: Arthur Lupia, Yanna Krupnikov, Adam Seth Levine, Spencer Piston and Alexander Von Hagen-Jamar, University of Michigan

Title: "Why State Constitutions Differ in the Treatment of Same-Sex Marriage"

\section{Best Graduate Paper Award}

The Best Graduate Paper Award is given for the best paper on state politics and policy presented by a graduate student at the previous year's APSA Annual Meeting. Award Committee: James King, University of Wyoming, chair; Elizabeth Rigby, University of Houston; Neal Woods, University of South Carolina

Recipient: Julianna Pacheco, Pennsylvania State University

Title: "Thermostatic Policy Responsiveness in the Fifty States"

\section{Christopher A. Mooney Dissertation Award}

This award is given for the best dissertation in American state politics and policy research.

Award Committee: Elizabeth Rigby, University of Houston, chair; Marjorie SarbaughThompson, Wayne State University; Todd Donovan, Western Washington University Recipient: Nicole D. Kazee, Yale University Title: "Wal-Mart Welfare: Business, Fiscal Regimes, and the Politics of Health Policy in the American States"

Dissertation Advisor: Jacob S. Hacker, Yale University

\section{SPPQ Award}

This award is given for the best paper on state politics and policy presented at any professional meeting in the previous calendar year.

Award Committee: Eric Plutzer, Pennsylvania State University; Beth Reingold, Emory University; Dennis Grady, Appalachian State University

Recipients: Jeffrey R. Lax and Justin $\mathbf{H}$. Phillips, Columbia University

Title: "Explaining Democratic Performance in the States"

\section{Career Achievement Award}

Award Committee: Ron Weber, University of Wisconsin, Milwaukee, chair; Andrew Karch, University of Texas; Nancy Martorano Miller, University of Dayton; Christopher Z. Mooney, University of Illinois, Springfield; Barbara Norrander, University of Arizona

Recipient: Ken Meier, Texas A\&M University

\section{SECTION 23: POLITICAL COMMUNI- CATION}

\section{Best Graduate Student Paper Award}

This award is given for the best paper on political communication presented by a graduate student at the previous year's APSA Annual Meeting.

Award Committee: Craig Brians, Virginia Tech, chair; Christopher Weber, Louisiana State University; Stephenie Burkhalter, Humboldt State University

Recipient: Dino Christenson, Ohio University

Title: "Learning from Campaigns: Political Information and Context in Presidential Elections"

\section{SECTION 24: POLITICS AND HIS-} TORY

\section{J. David Greenstone Award}

This award is given for the best book in politics and history published in the previous calendar year.

Award Committee: Elizabeth Sanders, Cornell University, chair; Kathleen Sullivan, Ohio University; Robert Lieberman, Columbia University

Co-Recipient: Anthony Chen, University of Michigan

Title: The Fifth Freedom: Jobs, Politics, and Civil Rights in the United States, 1941-1972 (Princeton University Press, 2009)

Co-Recipient: Eileen McDonagh, Northeastern University

Title: The Motherless State: Women's Political Leadership and American Democracy (University of Chicago Press, 2009)

\section{Mary Parker Follett Award}

The Mary Parker Follett Award is given for the best article or chapter in politics and history published in the previous two calendar years.

Award Committee: Eileen McDonagh, Northeastern University, chair; Sheldon Pollack, University of Delaware; Richard Ellis, Willamette University

Recipient: Stephen Skowronek, Yale University

Title: "The Conservative Insurgency and Presidential Power: A Developmental Perspective on the Unitary Executive," Harvard Law Review 122:2070

\section{Walter Dean Burnham Award}

The Walter Dean Burnham Award is given for the best dissertation in politics and history presented at the previous year's Annual Meeting.

Award Committee: Gerard Berk, University of Oregon, chair; Christopher Howard, College of William and Mary; Christopher S. Allen, University of Georgia

Recipient: Colin Destin Moore, Harvard University

Title: "Institutions of Empire: Information, Delegation, and the Political Control of American Imperialism, 1890-1913" Honorable Mention: Maya Jessica Tudor, Princeton University

Title: "Twin Births, Divergent Democracies: The Social and Institutional Origins of Regime Outcomes in India and Pakistan, 1920-1958"

\section{SECTION 25: POLITICAL ECONOMY \\ Best Paper Award}

The Best Paper Award is given for the best paper in political economy presented at the previous year's APSA Annual Meeting. Award Committee: Timothy Frye, Columbia University, chair; Mark Kayser, Hertie School of Governance, Berlin; Toke Aidt, University of Cambridge

Recipients: Torun Dewan, London School of Economics and Political Science, and David P. Myatt, University of Oxford Title: "On the Rhetorical Strategies of Leaders: Speaking Clearly, Standing Back, and Stepping Down"

Honorable Mention: Xiabo Lu and Kenneth F. Scheve, Yale University; Matthew J. Slaughter, Dartmouth College Title: "Envy, Altruism and the International Distribution of Trade Protection"

\section{William H. Riker Book Award}

The Best Book Award, named for William 
H. Riker, is given for the best book on political economy published during the past three calendar years.

Award Committee: Raymond M. Duch, University of Oxford, chair; Susan Rose-Ackerman, Yale University; Jessica Troustine, University of California, Merced

Recipient: Orit Kedar, Massachusetts Institute of Technology

Title: Voting for Policy, Not Parties: How Voters Compensate for Power Sharing (Cambridge University Press, 2009)

\section{Mancur Olson Award}

The Mancur Olson Award is given for the best dissertation completed and accepted in the previous two years.

Award Committee: Strom Thacker, Boston University, chair; Michael Tomz, Stanford University; Shigeo Hirano, Columbia University

Recipient: Stephen B. Kaplan, Yale University

Title: "From Spendthrifts to Misers: Globalization and Latin American"

\section{Michael Wallerstein Award}

The Michael Wallerstein Award is given for the best published article in political economy in the previous calendar year.

Award Committee: David S. Brown, University of Colorado, chair; Pablo Beramendi, University of Oxford; Karl Ove Moene, University of Oslo

Recipient: Moses Shayo, Hebrew University of Jerusalem

Title: "A Model of Social Identity with an Application to Political Economy: Nation, Class and Redistribution," American Political Science Review 103 (2)

\section{SECTION 27: NEW POLITICAL SCI- ENCE}

\section{Christian Bay Best Paper Award}

The Christian Bay Best Paper Award is given for the best paper presented at a New Political Science panel at the previous year's APSA Annual Meeting.

Award Committee: Daniel O'Connor, California State University, Long Beach, chair; Stefan Heumann, University of Northern Colorado; Jocelyn Boryczka, Fairfield University

Recipients: Brooke A. Ackerly and José Miquel Cruz, Vanderbilt University Title: "Hearing the Voice of the People: Human Rights as if People Mattered"

\section{Francis Fox Piven and Richard} Cloward Award
This award is given for an activist group, in the region of the Annual Meeting, that puts the ideals of the New Political Science Section "to make the study of politics relevant to the struggle for a better world" into practice.

Award Committee: Joel Lefkowitz, SUNY, New Paltz, chair; Immanuel Ness, Brooklyn College; Katie Young, Colorado State University; Frances Fox Piven, Honorary Recipient: ACORN

\section{Charles A. McCoy Career Achieve- ment Award}

The Charles A. McCoy Career Achievement Award is given for a progressive political scientist who has had a long, successful career as a writer, teacher, and activist. Award Committee: Laura Katz Olson, Lehigh University, chair; John Ehrenberg, Long Island University; Alethia Jones, University of Albany, SUNY

Recipient: John Berg, Suffolk University

\section{Michael Harrington Book Award}

The Michael Harrington Book Award is given for an outstanding book that demonstrates how scholarship can be used in the struggle for a better world.

Award Committee: Nicholas Kiersey, Ohio State University, chair; Wendy Sarvasy, California State University, East Bay; Jose R. Sanchez, Long Island University, Brooklyn Campus

Recipient: Marshall Ganz, Harvard University

Title: Why David Sometimes Wins: Leadership, Organization, and Strategy in the California Farm Worker Movement (Oxford University Press, 1980)

\section{SECTION 28: POLITICAL PSYCHOL-} OGY

\section{Best Dissertation Award}

Given for the best dissertation in political psychology filed during the previous year. Award Committee: Jason Barabas, Florida State University, chair; Paul Brewer, University of Wisconsin-Milwaukee; DonaGene Mitchell, University of NebraskaLincoln

Recipients: Eric Groenendyk, University of Michigan, and Danielle Shan, Princeton University

Title: "The Motivated Partisan: A Dual Motivations Theory of Partisan Change and Stability on the Origins of Political Interest"

\section{Robert Lane Best Book Award}

The Robert E. Lane Award is given for the best book in political psychology published in the past year.

Award Committee: Kristen Renwick Monroe, University of California, Irvine, chair; Michael Morrell, University of Connecticut; Joanne Miller, University of Minnesota

Co-Recipient: George A. Akerlof, University of California, Berkeley, and Robert J. Shiller, Yale University

Title: Animal Spirits: How Human Psychology Drives the Economy, and Why It Matters for Global Capitalism (Princeton University Press, 2009)

Co-Recipient: Elizabeth Theiss-Morse, University of Nebraska

Title: Who Counts As An American: The Boundaries of Natural Identity (Cambridge University Press, 2009)

\section{Best Paper Award}

The Best Paper Award is awarded to the authors of a paper in the area of political psychology that was presented during the previous year's APSA Annual Meeting. Award Committee: Thomas Rudloph, University of Illinois, chair; Eric Groenendyck, University of Memphis; Andy Civettini, Knox College

Recipients: Jamie Druckman and Toby Bolsen, Northwestern University

Title: "Framing, Motivated Reasoning, and Opinions about Emergent Technologies"

\section{SECTION 29: POLITICAL SCIENCE EDUCATION}

\section{Best Presentation Award}

The Best Presentation Award is given for the best presentation (be it in a paper, poster, or roundtable format) delivered in a session sponsored by the Undergraduate Education Section at the Annual Meeting. Award Committee: Danny Damron, Utah Valley University, chair; Craig L. Brians, Virginia Tech; Shannon Jenkins, University of Massachusetts, Dartmouth Recipients: John Ishiyama, Christine Balarezo, and Tom Miles, University of North Texas

Title: "Do Graduate Student Teacher Training Courses Affect Placement Rates?"

\section{SECTION 30: POLITICS, LITERA-}

TURE, AND FILM

\section{Wilson Carey McWilliams Best Paper Award}

The Wilson Carey McWilliams Best Paper Award is given for the best paper presented at the previous year's APSA Annual Meet- 
ing.

Award Committee: Charles T. Rubin, Duquesne University, chair; Sheena Chestnut, Harvard University; Sabeel Rahman, Harvard University

Recipient: James H. Read, College of Saint Benedict and Saint John's University Title: "The Limits of Self-Reliance"

SECTION 32: ELECTIONS, PUBLIC OPINION, AND VOTING BEHAVIOR

Best Paper Award on Elections and Voting

The Best Paper Award is given for the best paper delivered at the previous year's APSA Annual Meeting.

Award Committee: Peter Enns, Cornell University, chair; Christopher Anderson, Cornell University; Marc Hetherington, Vanderbilt University

Recipients: Deborah J. Brooks and Benjamin A. Valentino, Dartmouth College

Title: "A War of One's Own: Understanding the Gender Gap in Support for War"

\section{Emerging Scholar Award}

The Emerging Scholar Award is awarded to the top scholar in the field who is within 10 years of her or his Ph.D.

Award Committee: Helmut Norpoth, SUNYStony Brook, chair; R. Michael Alvarez, California Institute of Technology; Cherie Maestas, Florida State University

Recipient: James Fowler, University of California, San Diego

\section{John Sullivan Award}

This award is for the best paper by a graduate student on a panel sponsored by the APSA Organized Section on Elections, Public Opinion, and Voting Behavior at the previous APSA Annual Meeting. Award Committee: Peter Enns, Cornell University, chair; Christopher Anderson, Cornell University; Marc Hetherington, Vanderbilt University

Recipient: Elias Dinas, European University Institute

Title: "The More You Try the Less It Sticks: Parental Politicization and the Endurance of Partisan Transmission through the Family"

\section{Philip E. Converse Best Book Award}

The Philip E. Converse Book Award is given for an outstanding book in the field published five or more years ago.

Award Committee: James A. Stimson, University of North Carolina, Chapel Hill, chair; Patricia Hurley, Texas A\&M Uni- versity; Casey A. Klofstad, University of Miami

Recipients: Robert S. Erikson, Columbia University; Gerald C. Wright, Indiana University; John P. McIver, University of Colorado

Title: Statehouse Democracy: Public Opinion and Policy in the American States (Cambridge University Press, 1993)

\section{Warren Miller Prize}

The Warren E. Miller Prize is awarded every two or three years for an outstanding career of intellectual accomplishment and service to the profession in the elections, public opinion, and voting behavior field. Award Committee: Michael S. Lewis-Beck, University of Iowa; Paul Goren, University of Minnesota; Thomas Rudolph, University of Illinois

Recipient: James A. Stimson, University of North Carolina

SECTION 33: RACE, ETHNICITY, AND POLITICS

\section{Best Dissertation Award}

Given for the best dissertation in race, ethnicity and politics filed during the previous year.

Award Committee: Louis DeSipio, University of California, Irvine, chair; Barbara L. Graham, University of Missouri-St. Louis; Cara Wong, University of Illinois, UrbanaChampaign

Recipient: Sheryl R. Lightfoot, University of British Columbia

Title: "Indigenous Global Politics" (University of Minnesota)

SECTION 34: INTERNATIONAL HISTORY AND POLITICS

\section{Jervis and Schroeder Best Book} Award

The Robert L. Jervis and Paul W. Schroeder Prize for the best book on international history and politics published in the previous two years.

Award Committee: Kimberly J. Marten, Barnard College, chair; George Gavrilis, University of Texas at Austin; Andrew H. Kydd, University of Wisconsin-Madison

Recipient: Patrick J. McDonald, University of Texas, Austin

Title: The Invisible Hand of Peace: Capitalism, The War Machine, and International Relations Theory (Cambridge University Press, 2009)

\section{SECTION 35: COMPARATIVE DEMOCRATIZATION}

\section{Best Article Award}

The Best Article Award is awarded to single-authored or co-authored articles focusing directly on the subject of democratization and published in 2009.

Award Committee: Evan Lieberman, Princeton University, chair; Eva Bellin, City University of New York; Steven Levitsky, Harvard University

Co-Recipient: Dan Slater, University of Chicago

Title: "Revolutions, Crackdowns, and Quiescence: Communal Elites and Democratic Mobilization in Southeast Asia," American Journal of Sociology 115 (1): 203-54

Co-Recipient: Daniel Ziblatf, Harvard University

Title: "Shaping Democratic Practice and the Causes of Electoral Fraud: The Case of Nineteenth-Century Germany" American Political Science Review 103 (1): 1-21

\section{Best Paper Award}

The Best Paper Award is given to the best paper presented on a panel organized by the Comparative Democratization Section at the previous year's APSA annual meeting.

Award Committee: Scott Mainwaring, University of Notre Dame, chair; Henry Hale, George Washington University; Dan Slater, University of Chicago

Recipients: Giovanni Capoccia, Oxford University and Daniel Ziblatt, Harvard University

Title: "The Historic Turn in Democratization Studies: A New Research Program and Evidence from Europe"

\section{Best Book Award}

The Best Book Award is given for the best book in the field of comparative democratization published in 2009 (single authored, multi-authored, or edited).

Award Committee: Ann Grzymala-Busse, University of Michigan, chair; Jacques Bertrand, University of Toronto; Thad Dunning, Yale University

Recipients: Zachary Elkins, University of Texas, Austin; Tom Ginsburg, University of Chicago; James Melton, IMT-Institute for Advanced Studies

Title: The Endurance of National Constitutions (Cambridge University Press, 2009)

\section{Juan Linz Best Dissertation Award}

This award is given for the best dissertation in the field of comparative study of democracy completed and accepted in the past two calendar years. The comparative study 
of democracy includes analyses of individual country cases as long as they are clearly cast in a comparative perspective.

Award Committee: Catherine Boone, University of Texas, Austin, chair; Gerardo Munck, University of Southern California; Daniel Ziblatt, Harvard University Co-Recipient: Agustina Giraudy, University of North Carolina, Chapel Hill

Title: "Subnational Undemocratic Regime Continuity After Democratization: Argentina and Mexico in Comparative Perspective"

Co-Recipient: Evangelos (Evan) Liaras, Massachusetts Institute of Technology Title: "Ballot Box and Tinderbox: Can Electoral Engineering Save Multiethnic Democracy?"

\section{Best Field Research Award}

This prize rewards dissertation students who are currently working on their dissertations or completed theirs in 2009 who conduct especially innovative and difficult fieldwork.

Award Committee: Melani Cammett, Brown University, chair; Fotini Christia, Massachusetts Institute of Technology; Alexandra Scacco, Oxford University

Recipient: Alejandra Armesto, University of Notre Dame

Title: "Territorial Control and Particularistic Spending on Local Public Goods" (University of Notre Dame)

\section{SECTION 36: HUMAN RIGHTS}

\section{Best Dissertation Award}

Given for the best dissertation focused on human rights that was completed and accepted during the previous two calendar years.

Award Committee: Michael J. Struett, North Carolina State University, chair; Richard P. Hiskes, University of Connecticut; Carolyn Shaw, Wichita State University

Recipient: Andreas von Staden, Princeton University

Title: "Shaping Human Rights Policy in Liberal Democracies: Assessing and Explaining Compliance with the Judgments of the European Court of Human Rights"

\section{Distinguished Scholar Award}

This award is intended to recognize some- one who has worked in the field of human rights and made an exceptional contribution to the field through research, teaching and mentorship.

Award Committee: Rhoda E. Howard-Hassmann, Wilfrid Laurier University, chair; David P. Forsythe, University of Nebraska; Jack Donnelly, University of Denver Recipient: Zehra F. Kabasakal Arat, Purchase College, SUNY

\section{SECTION 37: QUALITATIVE AND MULTI-METHOD RESEARCH}

Alexander L. George Article Award

This award honors Alexander George's prominent role in developing and teaching qualitative methodology, in particular the comparative case study method.

Award Committee: Michael Tomz, Stanford University, chair; Emilie M. Hafner-Burton, University of California, San Diego; Dara Z. Strolovitch, University of Minnesota

Recipient: Dan Slater, University of Chicago

Title: "Revolutions, Crackdowns, and Quiescence: Communal Elites and Democratic Mobilization in Southeast Asia," American Journal of Sociology 115 (1): 203-54

\section{The Sage Paper Award}

This award honors the contribution of Sara and George McCune to the field of qualitative methods, through their role in founding Sage Publications and developing it into a leading publisher in the field of social science methodology.

Award Committee: Benjamin Read, University of California Santa Cruz, chair; Mirjam Kunkler, Princeton University; Ngoni Munemo, Williams College

Recipient: Marcus Kreuzer, Villanova University

Title: "Historical Knowledge and Quantitative Analysis: The Case of the Origins of Proportional Representation"

\section{Giovanni Sartori Book Award}

This award honors Giovanni Sartori's innovative research on social science concepts and his leading role in developing the field of concept analysis as a component of political science methodology.

Award Committee: Kathleen Thelen, Massachusetts Institute of Technology, chair;
Taylor Boas, Boston University; Jeffrey T. Checkel, Simon Fraser University

Co-Recipient: Edward Schatz, University of Toronto

Title: Political Ethnography: What Immersion Contributes to the Study of Power (University of Chicago Press, 2009)

Co-Recipient: Evan S. Lieberman, Princeton University

Title: Boundaries of Contagion: How Ethnic Politics Have Shaped Government Responses to AIDS (Princeton University Press, 2009)

\section{SECTION 38: SEXUALITY AND POLI-} TICS

\section{Sexuality and Politics Best Confer- ence Paper Award}

This award is given for the best paper exploring sexuality and politics presented at the previous year's APSA Annual Meeting.

Award Committee: Alesha E. Doan, University of Kansas, chair; Thomas M. Keck, Syracuse University

Recipient: Maxine Eichner, University of North Carolina School of Law

Title: "Feminism, Queer Theory, and Sexual Citizenship"

SECTION 40: CANADIAN POLITICS Mildred Schwartz Lifetime Achievement Award

This award honors Mildred Schwartz, who has been a luminary of comparative Canadian-U.S. scholarship and is well known in both countries. The award thus honors people who have been deemed to be leading scholars in bringing the study of Canadian politics to the international political science community.

Award Committee: Melissa Haussman, Carleton University; Ray Tatalovich, Loyola University Chicago; Patrick James, University of Southern California; Laura Stephenson, University of Western Ontario; Janna Ferguson, Rutgers University; Christopher Sands, Hudson Institute; Candace Johnson, University of Guelph; Louise Carbert, Dalhousie University; Pauline Rankin, Carleton University

Recipient: Jill M. Vickers, Carleton University 